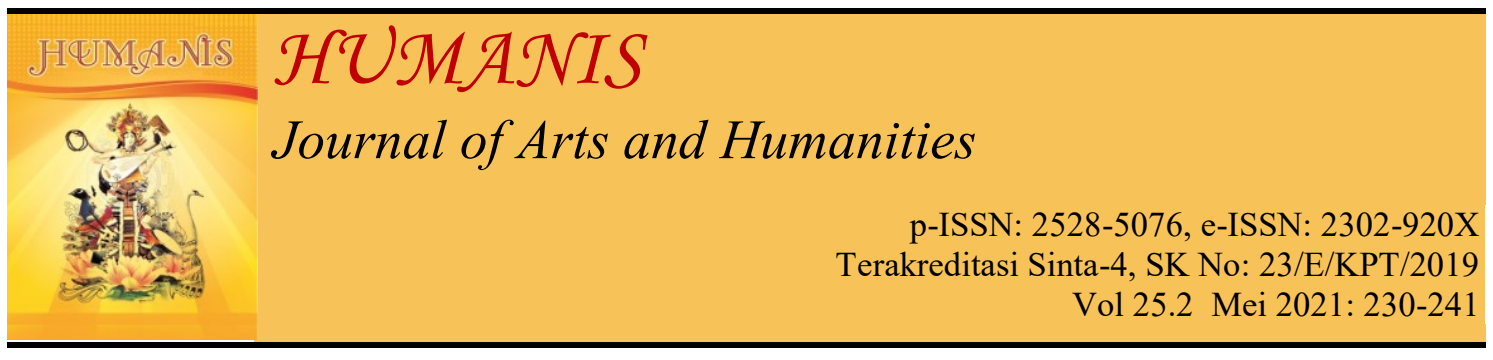

\title{
Pengembangan Desa Menuju Desa Wisata di Desa Timpag, Kabupaten Tabanan
}

\author{
Ida Bagus Mahardika A. P., Ida Bagus Gde Pujaastawa, I Wayan Suwena \\ Universitas Udayana, Denpasar, Bali, Indonesia \\ Email korespondensi: idabagusmahardika29@gmail.com,guspuja@gmail.com, \\ wsuwenas58@yahoo.com
}

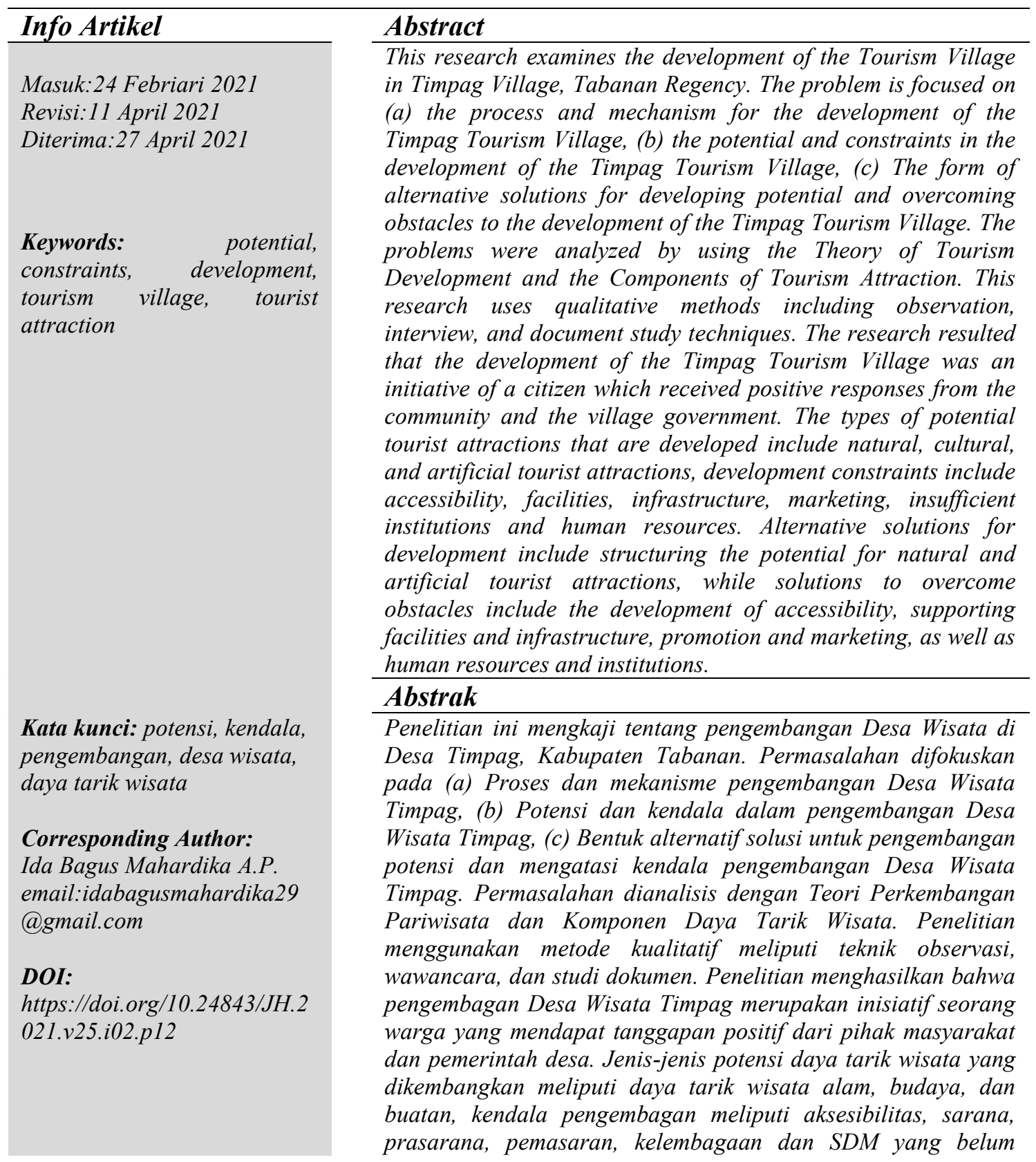


memadai. Alternatif solusi untuk pengembangan meliputi penataan potensi daya tarik wisata alam dan buatan, sedangkan solusi untuk mengatasi kendala meliputi pengembangan aksesibilitas, sarana dan prasarana penunjang, promosi dan pemasaran, serta SDM dan Kelembagaan.

\section{PENDAHULUAN}

Pariwisata memiliki peran penting karena merupakan salah satu sumber penerimaan devisa Negara dan mampu memberikan sumbangan yang cukup signifikan bagi pembangunan bangsa. Saat ini trend pariwisata mengalami perubahan, dari yang sebelumnya yaitu pariwisata konvensional berubah menjadi pariwisata minat khusus. Pada pariwisata minat khusus wisatawan berkecederungan lebih menghargai lingkungan, alam, budaya dan atraksi secara spesial. Salah satu pariwisata minat khusus yang sedang berkembang di Indonesia adalah desa wisata(Priyanto \& Safitri, 2016).

Pengembangan kepariwisataan dapat membawa banyak manfaat dan keuntungan. Pembangunan kepariwisataan diarahkan pada peningkatan pariwisata menjadi sektor andalan yang mampu menyaingi kegiatan ekonomi lainnya, termasuk kegiatan sektor lain yang terkait(Masitah, 2019).

Desa Timpag merupakan salah satu desa di Bali yang memiliki potensi alam serta kondisi lingkungannya yang masih alami dan belum banyak tersentuh pembangunan akomodasi pariwisata. Berbekal potensi yang dimiliki, Pemerintah Kecamatan Kerambitan berupaya mengembangkan potensi Desa Timpag sebagai daya tarik wisata, dan membentuk pengelola dalam rangka pengembangan desa wisata dengan mengemas menjadi daya tarik wisata yang diawali dengan pembangunan daya tarik wisata Uma Urip yakni daya tarik wisata berupa jogging trek, kuliner, pendidikan dan pelestarian lingkungan, Undagi Farmes Village yakni daya tarik wisata religi berupa pancuran bermata tujuh, daya tarik wisata D'Bendungan View yakni daya tarik wisata berupa spot foto dengan pemandangan bendungan

Telaga Tunjung berlatar belakang panorama Gunung Batukaru dan dilengkapi kuliner khas Desa Timpag, daya tarik wisata Titi Empag River Tubing yaitu wisata air dengan memanfaatkan saluran irigasi yang bersumber langsung dari air Telaga Tunjung. Pemerintah Kecamatan Kerambitan mencoba mensinergikan daya tarik wisata itu melalui ajang Alam Timpag, tujuannnya agar ke depan tidak ada persaingan antara daya tarik wisata yang satu dengan yang lainnya. Pemerintah berupaya menggabungkan daya tarik wisata yang ada untuk dijadikan sebuah paket wisata. Jika pengembangan potensi pariwisata Desa Timpag sudah memadai dan berjalan sesuai harapan maka akan diajukan menjadi desa wisata.

Meskipun didukung oleh sejumlah potensi kepariwisataan, namun hingga sejauh ini pengembangan Desa Wisata Timpag masih terasa belum optimal. Hal ini antara lain dibuktikan dengan pihak pengelola yang belum memiliki perencanaan yang jelas, pengelola langsung melakukan suatu tindakan tanpa perencanaan yang matang, sehingga pembangunan fasilitas umum, prasarana penunjang, dan prasarana wisata masih minim dan dihadapkan dengan permasalahan dana selain itu kesadaran masyarakat diluar pihak pengelola belum semuanya memiliki satu visi mengembangkan desa wisata.

Berdasarkan latar belakang masalah yang telah dijelaskan, maka penelitian ini 
dapat merumuskan permasalahan yaitu (1) Bagaimana proses dan mekanisme pengembangan Desa Wisata Timpag dilihat dari tahap-tahap perkembangan pariwisata ? (2) Bagaimana potensi dan kendala dalam rangka pengembangan Desa Wisata Timpag ? (3) Bagaimana bentuk alternatif solusi untuk pengembangan potensi dan mengatasi kendala pengembangan Desa Wisata Timpag?

Lokasi penelitian ini berada di Desa Timpag, Kabupaten Tabanan. Alasan memilih lokasi penelitian di Desa Timpag dikarenakan adanya upaya masyarakat mengembangkan Desa Timpag menjadi desa wisata dengan memanfaatkan potensi desa untuk dikembangkan sebagai daya tarik wisata.

\section{METODE DAN TEORI}

Penelitian ini menggunakan metode penelitian kualitatif. Teknik pengumpulan data penelitian ini dilakukan dengan cara observasi, wawancara mendalam dan studi kepustakaan. Penelitian ini juga menggunakan Teori Perkembangan Pariwisata, Teori Komponen Daya Tarik Wisata yang dianggap relevan dalam mengkaji permasalahan penelitian ini.

\section{HASIL DAN PEMBAHASAN}

\section{Proses dan Mekanisme Pengembangan Desa Wisata Timpag Dilihat Dari Tahap-tahap Perkembangan Pariwisata}

Perkembangan pariwisata berlangsung melalui 3 tahap yaitu: Tahap Penemuan (Discovery), Tahap munculnya Tanggapan dan Inisiatif Lokal (Local Response), Tahap Institusionalisasi

(Institusionalized)(Pujaastawa, 2019: 2325).

a. Tahap Penemuan (Discovery)
Pada tahap ini ide pengembangan Desa Timpag menjadi Desa Wisata berawal dari Desa Timpag sebagai jalur perjalanan wisata menuju daya tarik wisata Gunung Batukaru, daya tarik wisata Air Panas Penatahan, daya tarik wisata Jati Luwih, kemudian salah seorang warga masyarakat desa timpag yakni Bapak I Gusti Wayan Sukawahana beliau adalah Kepala Desa Timpag periode tahun 2010-2015, beliau melihat sejumlah potensi yang dimiliki Desa Timpag untuk dikembangkan menjadi daya tarik wisata,

b. Tahap Munculnya Tanggapan dan Inisiatif Lokal (Local Response)

Pada tahap ini berkat penyampaian kepada masyarakat Desa Timpag mengenai potensi yang ditemukan oleh penemunya, kemudian masyarakat desa timpag memberikan tanggapan positif dalam mendukung terbentuknya Desa Timpag menjadi Desa Wisata, kemudian masyarakat mengambil inisiatif untuk mau bekerja sama dalam membantu mewujudkan terbentuknya Desa Timpag menjadi Desa Wisata.
c. Tahap Institusionalisasi Institusionalized)

Pasca dibentuknya daya tarik wisata dikawasan Desa Wisata Timpag, para wisatawan mulai datang untuk mengunjungi tempat tersebut. Untuk meningkatkan jumlah kunjungan pihak pengelolaan pariwisata melakukan upaya-upaya untuk meningkatkan kualitas dan kwantitas Sumber Daya Manusia (SDM) dibidang kepariwisataan yang di fasilitasi oleh pemerintah yang dilakukan oleh Kementrian Pariwisata dan Ekonomi Kreatif. Adapun upayaupaya yang dilakukan seperti pengembangan kemampuan dalam berbahasa asing, meningkatkan kemampuan dalam melayani wisatawan yang berkunjung juga dibentuk organisasi atau lembaga-lembaga yang berkaitan dengan dunia kepariwisataan. 
Demikian pula sarana dan prasarana kepariwisataan juga semakin ditingkatkan, sehingga pengungjung yang melakukan kegiatan wisata akan meninggalkan kesan yang baik pula dan menanamkan suatu perasaan untuk kembali berkunjung pada waktu yang lain.

\section{Potensi dan Kendala Dalam Rangka Pengembangan Desa Wisata Timpag}

a. Potensi dalam rangka pengembangan Desa Wisata Timpag:

Potensi wisata adalah segala sesuatu yang terdapat di daerah tujuan wisata dan merupakan daya tarik agar orang-orang mau datang berkunjung ke tempat tersebut(Pramesti, 2018). Desa Timpag memiliki potensi wisata yang cukup besar untuk dikembangkan sebagai daya tarik wisata. Daya Tarik Wisata merupakan mata rantai terpenting dalam suatu kegiatan wisata, hal ini disebabkan karena faktor utama yang membuat pengunjung atau wisatawan untuk mengunjungi daerah tujuan wisata adalah potensi dan daya tarik yang dimiliki wilayah tersebut(Devy \& Soemanto, 2017). Adapun potensi wisata Desa Timpag seperti:

- Potensi alam berupa pemandangan hamparan persawahan dengan luas 375 hektar yang menghijau dengan suasana perdesaan dan aktivitas bertani di sawah, sungai, habitat Burung Hantu Tyto Alba, Pancuran Bermata Tujuh tempat pembersihan diri (melukat), Air Terjun.

- Potensi budaya seperti Rumah Tradisional Bali, Seni Tari dan Pertunjukan Tradisional, Produk Minyak Kelapa Tradisonal dan Kuliner Khas Desa Timpag

- Potensi buatan seperti Bendungan Telaga Tunjung sebagai tempat penampungan irigasi dan menawarkan pemandangan yang menarik, area joggng yang dapat digunakan pengunjung berolahraga sambil menikmati keindahan alam Desa Timpag dan Spot foto hasil karya masyarakat yang menarik seperi berbentuk helicopter, hati, jebatan, dan bunga Teratai. Adanya spot foto ini diharapkan dapat menarik wisatawan untuk berkunjung.

b. Kendala dalam rangka pengembangan Desa Wisata Timpag

Dalam pengembangan desa wisata, tentu tidak luput dari permasalahanpermasalahan ataupun kendala yang tidak ringan(Raharjana, 2012). Permasalahan / kendala yang dihadapi antara lain :

\section{Aksesibilitas}

Aksesibilitas merupakan daya hubung antar zona yang wujudnya berupa jalan raya dan jaringan angkutan. Aksesibilitas merupakan faktor penting dalam proses berwisata, tingkat kemudahan untuk menjangkau suatu kawasan wisata dilihat dari aksesibilitas yang berupa kondisi jalan raya, ketersediaan moda angkutan untuk menuju kawasan wisata tersebut (Ghani, 2017). Akses jalan menuju Desa Timpag sudah tersedia namun saat ini kurang baik dengan kodisi jalan yang sempit dan beberapa bagian jalan yang rusak dan perlu dilakukan pelebaran dan perbaikan jalan agar jalur transportasi menjadi lebih lancar, mengingat bahwa hampir setiap destinasi wisata memerlukan lebar jalan yang cukup untuk dilalui oleh transportasi masal seperti bus, mobil pribadi dan angkutan umum.

\section{Sarana dan Prasarana}

Sarana dan prasarana sangat mempengaruhi tingkat minat pengunjung suatu tempat pariwisata. Karena jika suatu tempat wisata memiliki fasilitas sarana dan prasana yang kurang memenuhi standart, maka dapat menurunkan minat untuk mendatangi tempat wisata tersebut (Suchaina,2014). 
Dalam rangka pengembangan Desa Wisata Timpag ketersediaan sarana dan prasarana masih menjadi kendala dikarenakan belum tersedianya sarana dan prasarana seperti:

- Sarana Akomodasi

Sarana akomodasi untuk tempat peristirahatan saat ini belum tersedia, sehingga belum mampu melayani kebutuhan para wisatawan yang ingin beristirahat ataupun menginap dikawasan Desa Wisata Timpag

- Sarana Penyedia Pangan

Untuk sarana jasa pangan berupa warung/rumah makan yang ada di Desa Timpag pada saat ini masih sedikit dan belum mampu melayani kebutuhan wisatawan yang datang berkunjung.

○ Toilet Umum saat ini ketersediaan toilet umum dikawasan wisata Desa Wisata Timpag belum tersedia, sehingga terkendala dalam memenuhi kebutuhan para wisatawan yang berkunjung, jika pengunjung memerlukan toilet, untuk saat ini para pengunjung memanfaatkan toilet yang ada pada rumah / warung milik warga desa.

- Lahan Parkir sarana perparkiran pada lokasi kawasan wisata Desa Wisata Timpag masih terdapat kendala karena belum tersedianya lahan parkir, sehingga para wisatawan / pengunjung memanfaatkan badan jalan sebagai tempat parkir sehingga mengganggu aktifitas masyarakat dan pengunjung / wisatawan lainnya.

- Toko Cinderamata

Toko Cinderamata pada kawasan wisata Desa Wisata Timpag belum tersedia, sehingga belum mampu memenuhi kebutuhan wisatawan untuk mendapatkan cinderamata / barang-barang yang dapat mengingat kembali bahwa wisatawan pengunjung tersebut pernah berkungjung di Desa Wisata Timpag.

- Jaringan Air Bersih

ketersediaan air bersih belum maksimal dengan keadaan masih menggunakan air bersih yang bersumber dari sumur dengan kualitas air terasa payau dalam menunjang aktifitas di kawasan Desa Wisata Timpag dan terkendala pada saat musim kemarau sumur yang biasanya dijadikan suber air bersih kering.

- Jaringan Listrik

Jaringan listrik di kawasan Desa Wisata Timpag, sudah tersedia hanya saja pada daya tarik wisata belum semua terdapat jaringan listrik hal ini tentunya menjadi kendala dalam kegiatan kepariwisataan khususnya saat memerlukan jaringan listrik

- Jaringan Telekomunikasi

Jaringan telekomunikasi di Kawasan Desa Timpag, sudah tersedia namun ketersediaan jaringan masih sangat kurang terutama ketika pengunjung menggunakan jaringan internet hanya bisa menggunkan jaringan telkomsel

- Drainase

kondisi drainase yang ada belum berfungsi dengan baik hal ini disebabkan oleh kurangnya kesadaran dan partisipasi masyarakat, sehingga pada saat musim hujan drainase tersebut belum mampu mengalirkan air sebagaimana mestinya.

- Jaringan Persampahan jaringan persampahan di kawasan Desa Wisata Timpag sudah terdapat tempat sampah namun tak sebanding dengan luasnya wilayah Desa Wisata Timpag dengan keberadaan jumlah tempat persampahan yang terbatas, sehingga lingkungan pada kawasan Desa Wisata Timpag terkesan kotor yang ditandai masih banyaknya sampah yang berserakan sehingga 
mengurangi keindahan Desa Wisata Timpag.

\section{Promosi dan Pemasaran}

\section{Kendala Promosi}

Promosi adalah suatu cara yang digunakan untuk menginformasikan atau mengkomunikasikan kepada calon pembeli tentang produk yang ditawarkan dengan memberitahukan tempat-tempat dimana wisatawan dapat melihat atau melakukan pembelian produk pada waktu dan tempat tertentu(Triyono et al., 2018). Dalam hal ini kegiatan promosi dalam rangka pengembangan Desa Wisata Timpag masih menjadi kendala karena kegiatan promosi yang dilakukan pihak pengelola masih terhitung kurang efektif dikarenakan kurangnya kemampuan dan kreativitas pihak pengelola dalam menginformasikan atau mengkomunikasikan suatu produk wisata yang ada.

\section{Kendala Pemasaran}

Pemasaran merupakan suatu proses sosial manajerial yang di dalamnya individu dan kelompok mendapatkan apa yang mereka butuhkan dan inginkan dengan menciptakan, menawarkan dan mempertukarkan produk yang bernilai dengan pihak lain(Diniaty \& Agusrinal, 2014). Dalam hal ini pemasaran juga merupakan kendala besar yang dihadapi pengelola. hal yang dilakukan pengelola dalam praktik / pelaksanaan pemasaran masih terhitung sangat kurang dimana kendala dalam praktik / pelaksanaanya yang paling mendasar yaitu kurang efektif dan efisien dalam melakukan pemasaran. Hal ini dikarenakan kurangnya pengetahuan serta pengalaman pihak pengelola dalam melaksanakan pemasaran suatu produk wisata.

\section{SDM dan Kelembagaan}

SDM (sumber Daya Manusia) dalam bidang pariwisata memegang peranan penting dalam menggerakkan roda industri ini. Dengan memiliki SDM pariwisata yang memiliki kompetensi yang baik, maka pembangunan pariwisata dapat dilakukan secara optimal (Pajriah, 2018). Keberadaan SDM dalam rangka pengembangan Desa Wisata Timpag masih menjadi kendala dikarenakan kurangnya pengetahuan dan pemahaman dalam melayani wisatawan yang berkunjung.

Kelembagaan dalam bidang pariwisata adalah suatu organisasi yang berperan sebagai wadah sekaligus penggerak dalam memfasilitasi, dan mengembangkan partisipasi masyarakat dalam bidang pariwisata (Prafitri\&Damayanti,2016).

Kelembagaan dalam rangka pengembangan Desa Wisata Timpag masih menjadi kendala karena belum memiliki organisasi pembagian tugas yang jelas sehingga perlu pengembangan supaya tercipta organisasi pengelola yang professional.

\section{Bentuk Alternatif Solusi Untuk Pengembangan Potensi dan Mengatasi Kendala Pengembangan Desa Wisata Timpag}

a. Bentuk alternatif solusi untuk pengembangan potensi

Pengembangan potensi pariwisata yang dilakukan dengan baik akan mampu menarik wisatawan domestik maupun wisatawan asing untuk datangdan membelanjakan uangnya dalam kegiatan berwisatanya (Syahrul,2015). Pengembangan potensi yang dimiliki Desa Timpag dilakukan dengan penataan potensi alam dan buatan serta memanfaatkan potensi budaya sebagai daya tarik agar dapat dinikmati oleh wisatawan menarik wisatawan untuk berkunjung. Pengembangan potensi tersebut dilakukan dengan : 
- Penataan kawasan persawahan agar dapat menarik wisatawan sehingga dapat difungsikan sebagai tempat untuk rekreasi.

- Penataan pancuran bermata tujuh menjadi daya tarik wisata berupa destinasi wiasata religi yang berfungsi untuk wisatawan melakukan aktivitas keagamaan yaitu Melukat / pesucian secara rohani artinya menghilangkan pengaruh kotor dalam diri.

- Penataan sungai agar dapat dijadikan tempat untuk rekreasi wisata air seperti yang sudah mulai dibentuk yaitu berupa daya tarik wisata yang diberi nama Titi Empag River Tubing yaitu daya tarik wisata dengan menyediakan aktivitas wisata air sehingga wisatawan dapat meluncur bebas di sungai dengan menggunakan ban beserta alat keamanan yang sudah disediakan oleh pengelola.

- Memanfaatkan rumah tradisional bali milik warga sebagai daya tarik dan sarana aloodasi agar pengunjung / wisatawan dapat menikmati keindahan arsitektur serta dapat merasakan suasana rumah tradisional bali.

- Penataan Bendungan Telaga Tunjung yang awalnya hanya sebagai sarana penyedia air untuk irigasi. agar dapat difungsikan sebagai tempat rekreasi dengan membangun rumah makan dan tempat bersantai sehingga para wisatawan / pengunjung dapat beristirahat / bersantai sembari menikmati keindahan bendungan telaga tunjung. selain itu bendungan telaga tunjung juga bisa difungsikan untuk tempat untuk melakukan aktivitas seperti memancing ikan bagi pecinta mancing.

- Membangun spot foto yang menarik agar para pengunjung atau wisatawan dapat mengabadikan moment ketika mengunjungi Desa Wisata Timpag.

- Penataan penangkaran burung hantu Tyto Alba dengan tujuan melestarikan keberadaan burung hantu Tyto Alba yang berfungsi untuk membasmi hama tikus dengan membuat rumah burung hantu (rubuha) di sawah warga agar burung hantu yang tidak memiliki tempat untuk bersarang dapat bersarang di rubuha. Selain untuk melestarikan keberadaan burung hantu Tyto Alba tujuan dikembangkannya penangkaran Burung Hantu Tyto Alba juga difunsikan untuk untuk kegaiatan wisata berupa wisata edukasi kepada masyarakat mengubah paradigma petani dalam pembasmian hama tikus yang sering menggunakan zat kimia, ditambah lagi dengan penataan tanaman hias yang mempercantik daya Tarik wisata tersebut.

b. Bentuk alternatif solusi untuk mengatasi kendala

Solusi dalam mengatasi kendala dalam rangka pengembangan Desa Wisata Timpag dilakukan dengan cara :

\section{Pengembangan Aksesibilitas}

Pengembangan aksesibilitas bertujuan memudahkan wisatawan menuju lokasi wisata. Pengembangan aksesibilitas dapat dilakukan dengan pengembangan jalan, transportasi, petunjuk arah dan lain-lain (Khotimah et al., 2017). Pengembangan aksesibilitas dalam rangka pengembangan Desa Wisata Timpag bertujuan untuk memingkatkan kemudahan dan kenyamanan pengunjung dalam mencapai lokasi. Pengembanga aksesibilitas dalam hal ini dilakukan dengan perbaikan dan pelebaran jalan yang rusak dan peningkatan kwalitas jalan serta menambahkan papan penunjuk jalan agar memudahkan wisatawan menuju lokasi.

2. Pengembangan Sarana dan Prasarana Penunjang

Pengembangan sarana dan prasarana sangatlah penting dalam menunjang kegiatan pariwisata (Fajriah \& 
Mussadun, 2014). Dalam pengembangan pariwisata sarana dan prasarana yang dibutuhkan perlu dipersiapkan secara baik untuk menunjang kelancaran kegiatan pariwisata seperti pengadaan dan perbaikan sarana dan prasarana di sekitar lokasi kawasan wisata sangat diperlukan(Mustikawati, et all, 2017).

Pengembangan sarana dan prasarana dalam rangka pengembangan Desa Wisata Timpag dilakuakan denngan :

- Penyediaan Sarana Akomodasi

Penyediaan Sarana akomodasi dalam rangka menyediakan tempat untuk wisatawan menginap dilakukan dengan memanfaatkan rumah penduduk untuk tempat pengunjung menginap.

- Penyediaan Sarana Penyedia Pangan dilakukan dengan membangun restaurant / rumah makan dan membangun warung/ kios yang menjual berbagai makanan dan minuman.

- Penyediaan Toilet Umum

membangun toilet umum di setiap daya tarik wisata yang ada, sehingga dengan disediakannya toilet umum disetiap daya tarik wisata para pengunjung tidak lagi kesulitan dalam mencari toilet ketika ingin membersihkan diri atau buang air/

- Penyediaan Lahan Parkir

Dilakukan dengan cara membangun tempat parker pada Kawasan Desa Wisata Timpag maka para pengunjung dapat memarkirkan kendaraan yang digunakan dan tidak mengganggu aktivitas masyarakat dan pengunjung lainnya.

- Penyediaan Toko Cinderamata

Penyediaan toko cinderamata dikawasan Desa Wisata Timpag dimaksudkan untuk memenuhi kebutuhan pengunjung dalam mendapatkan cinderamata agar para pengunjung memiliki barang-barang yang dapat mengingat bahwa pernah berkunjung ke Desa Timpag penyediaan cinderamata juga bertujuan agar Desa Wisata Timpag sebagai daerah tujuan wisata bisa dikenal seperti daerah tujuan wisata lainnya. Adapun jenis-jenis cinderamata yang sediakan seperti : Kerajinan Batok Kelapa yang di bentuk menjadi aksesoris untuk perempuan seperti jepit rambut, kancing baju, bingkai photo, peralatan dapur seperti mangkuk dan sendok, selain itu juga ada kerajinan tangan berupa kerjinan anyaman, bahan-bahan anyaman yang digunakan seperti pandan, bambu, rotan, jerami, daun lontar dan ata. Hasil kerajinan dihasilkan berupa tas, dompet, bakul, tikar, ingke, kursi bahkan patung dibuat dengan gaya klasik dan natural, sehingga tampil unik dan indah sebagai barang hasil kerajinan. Selain kerajinan tangan terdapat juga cinderamata berupa minyak kelapa tradisional yang memiliki banyak manfaat untuk memasak dan untuk Kesehatan.

- Pengembangan Jaringan Air Bersih meningkatkan suplay air bersih dari PDAM dan menampung dengan dengan alat penampungan untuk keperluan wisatawan dan disesuaikan dengan kebutuhan masing-masing fasilitas yang akan dikembangkan.

- Penyediaa Jaringan Listrik Menyediakan jaringan listrik pada setiap daya tarik wisata dan juga berkerja sama dengan pihak aparat desa untuk menyediakan jaringan listrik untuk menunjang kegiatan kepariwisataan seperti untuk menambah peneranag jalan.

- Pengembangan Jaringan Telekomunikasi

Dengan menyediakan fasilitas beruupa wifi gratis harapan kami juga agar dapat menarik perhatian masyarakat untuk berkunjung 
- Pengembangan Drainase

Pengembangan Drainase dilakukan dengan cara memperbaiki jaringan drainase dan meningkatkan kesadaran dan partisipasi masyarakat untuk tidak membuang sampah sembarangan sehingga pada saat musim hujan drainase tersebut mampu mengalirkan air sebagaimana mestinya sehingga mendukung dalam melaksanakan kegiatan kepariwisataan.

- Penyediaan Tempat Sampah dan Sosialisasi mengenai pengolahan sampah

Tujuan dari kegiatan ini yaitu untuk menciptakan lingkungan yang sehat serta mengubah perilaku masyarakat agar tidak membuang sampah sembarangan dan memberikan pemahaman kepada masyarakat bahwa sampah juga berbahaya. Kurangnya kesadaran masyarakat dalam pengelolaan sampah. Program ini dibuat untuk membantu masyarakat berkreasi kreatif dan inovatif menggunakan barang bekas terutama sampah plastik yang selama ini dianggap sebagai barang tidak berharga.

\section{Pengembangan Promosi dan Pemasaran}

Pengembangan Promosi adalah suatu cara atau teknik yang digunakan untuk menawarkan produk wisata dengan menginformasikan kepada calon wisatawan dan dapat ditempuh dengan cara memberitahukan tempat-tempat dimana wisatawan dapat melihat atau melakukan pembelian produk wisata dengan waktu dan tempat tertentu. Kegiatan promosi yang dilakukan merupakan salah satu upaya untuk mengenalkan suatu produk wisata. Peningkatan aktivitas promosi wisata dapat dilakukan melalui produk dan jasa kreatif yang dapat dimanfaatkan sebagai alat untuk mempromosikan destinasi
pariwisata(Lstari, et all, 2016). Dalam hal ini pengembangan promosi dilakukan dengan cara memperkenalkan / suatu Destinasi Wisata dan Daya Tarik Wisata kepada agen perjalanan wisata / travel agent agar Desa Wisata Timpag dapat dikenal oleh masyarakat luas serta mampu meningkatkan jumlah kunjungan. Selain itu untuk mengembangkan promosi pihak pengelola Desa Wisata Timpag juga akan melaksanakan promosinya melalui media cetak elektronik dengan cara : mencetak brosur yang menarik, dengan mencantumkan segala daya tarik wisata, akomodasi, tarif daya tarik wisata, serta fasilitas yang hendak di perkrnalkan kepada masyarakat. Selain itu pihak pengelola juga memperkenalkaanya dengan membuat media sosial khusus untuk mempromosikan daya tarik wisata yang ada dengan cara memposting gambar daya tarik wisata dan mencantumkan penjelasan tentang jenis-jenis atraksi yang tesedia dan akomodasi, tarif daya tarik wisata, serta fasilitas yang tersedia di Desa Wisata Timpag.

Pengembangan pemasaran

Pengembangan pemasaran adalah suatu strategi dan rencana pemasaran yang mendalam dan kreatif yang dapat memandu kegiatan pemasaran. Pengembangan strategi pemasaran yang benar sepanjang waktu memerlukan bauran disiplin dan fleksibilitas. Pihak pengelola harus tetap berpegang pada strategi, tetapi juga menemukan cara baru untuk terus mengembangkannya (Rusilowati \& Atmaja 2019). Pengembangan pemasaran dalam rangka pengembangan Desa Wisata Timpag yang dilakukan dengan cara menjalin kerjasama dengan agen perjalanan wisata dan memasarkannya dengan cara menggabungkan daya tarik wisata yang ada untuk dijadikan sebuah paket wisata. 
4. Pengembangan SDM dan Kelembagaan

Pengembangan SDM dalam industri pariwisata dapat dilakukan melalui peningkatan kualitas pendidikan dan pelatihan yang tepat (Setiawan, 2016). Dalam hal pengembangan SDM dalam rangka pengembangan Desa Wisata Timpag pihak pengelola melakukan pertemuan rutin kepada masyarakat dalam pengenalan khususnya dalam bidang pariwisata seperti misalnya tentang pengenalan mengenai pariwisata khususnya Desa Wisata yang akan dikelola oleh masyarakat agar masyarakat dapat berperan sebagai tuan rumah yang baik bagi para wisatawan yang berkunjung, pelatihan ketrampilan dalam melayani pengunjung, pelatihan berbahasa asing, dan manfaat yang dihasilkan dalam pengembangan Desa Wisata serta peluang yang dapat dikembangkan dari kegiatan pariwisata untuk meningkatkan kesejahteraan ekonomi masyarakat.

Pengembangan

Kelembagaaan pariwisata, merupakan sebuah upaya untuk memperkuat program pariwisata di desa, mulai dari proses pembuatan kebijakan, pengaturan kewenangan, sistem organisasi dan pola komunikasi elemen yang terlibat dalam teknis penyelenggaraan pariwisata di desa, kemudian dilanjutkan dengan pemetaan potensi wilayah, hingga penentuan model serta jenis wisata yang akan diterapkan, setelah itu kemudian diidentifikasi permasalahan permasalahan yang dapat mengancam atau menggangu jalannya kepariwisataan di desa, yang terakhir yaitu roses pelaksanaan program pariwisata dan evaluasi dalam tahapan ini juga dimasukan item-item seperti publikasi dan evaluasi berkala, untuk memaksimalkan efek yang akan ditimbulkan di kemudian hari (Hilman,2017). Dalam hal ini pengembangan kelembagaan dilakukan dengan membentuk suatu organisasi yang bertugas untuk mengelola daya tarik wisata, daya tarik wisata, kegiatan pariwisata, sarana dan prasarana pariwisata, promosi dan pemasaran. Selain itu pengembangan kelembagaan juga bertujuan membentuk pihak pengelola yang bertugas dalam perencanaan, pelaksanaan dan evaluasi mengenai kegiatan pengembangan Desa Wisata Timpag.

\section{SIMPULAN}

Berdasarkan penelitian yang telah dilaksanakan maka dapat diperoleh kesimpulan: Potensi yang dimiliki dalam upaya menunjang pengembangan Desa Wisata Timpag terdiri dari potensi alam yaitu : kawasan persawahan, pancururan bermata tujuh, habitat burung hantu tyto alba. Potensi budaya yaitu arsitektur rumah tradisional bali dan aktivitas keseharian masyarakat. Potensi buatan yaitu bendungan telaga tunjung, spot foto. Beberapa kendala terkait dengan pengembagan Desa Wisata Timpag meliputi aksesibilitas, sarana dan prasarana, pemasaran, serta kelembagaan dan SDM yang belum memadai. Alternatif solusi yang ditawarkan untuk pengembangan potensi daya tarik wisata meliputi penataan potensi daya tarik wisata alam dan buatan. Solusi untuk mengatasi kendala meliputi pengembangan aksesibilitas, sarana dan prasarana penunjang, promosi dan pemasaran, serta SDM dan Kelembagaan.

Pengembangan Penelitian berikutnya diharapkan berkaitan dengan Potensi dan Kendala Pengembangan Desa Wisata di Desa Timpag, Kabupaten Tabanan diharapkan agar kajian yang dilakukan lebih mendalam lagi untuk menyempurnakan hasil penelitian terkait proses dan mekanisme perkembangan pariwisata dan keberadaan potensi serta solusi untuk mengatasi kendala dalam 
rangka pengembangan Desa Wisata Timpag.

\section{DAFTAR PUSTAKA}

Devy, H.A., \& Soemanto, R.B., (2017). Pengembangan Obyek dan Daya Tarik Wisata Alam Sebagai Daerah Tujuan Wisata di Kabupaten Karanganyar. Jurnal Sosiologi DILEMA, 32(1).

Diniaty, D., \& Agusrinal. (2014). Perancangan Strategi Pemasaran Pada Produk Anyaman Pandan. Jurnal Sains, Teknologi dan Industri, 11(2).

Fajriah, S.D., \& Mussadun. (2014). Pengembangan Sarana dan Prasarana untuk Mendukung Pariwisata Pantaiyang Berkelanjutan (StudiKasus: KawasanPesisir Pantai Wonokerto Kabupaten Pekalongan). Jurnal Pembangunan Wilayah dan Kota, 10(2).

Ghani, Y.A. (2017). Pengembangan Sarana Prasarana Destinasi Pariwisata Berbasis Budaya di Jawa Barat. Jurnal Pariwisata, 4(1).

Hilman, Y.A. (2017). Kelembagaan Kebijakan Pariwisata Di Level Desa. Jurnal Ilmu Pemerintahan, 2(2)

Khotimah, K., Wilopo.,Hakim, L. (2017). Strategi Pengembangan Destinasi Pariwisata Budaya (Studi Kasus pada Kawasan Situs Trowulan sebagai Pariwisata Budaya Unggulan di Kabupaten Mojokerto). Jurnal Administrasi Bisnis, 41(1)
Lestari, A., Sunarti., Pangestuti,E. (2016). Analisis Pengembangan Promosi Dalam Upaya Menarik Kunjungan Wisatawan (Studi Pada Taman Rekreasi Kota Malang). Jurnal Administrasi Bisnis, 40(1).

Masitah, I., (2019) Pengembangan Desa Wisata Oleh Pemerintah Desa Babakan Kecamatan Pangandaran Kabupaten Pangandaran. Jurnal Ilmiah Ilmu Administrasi Negara, 6(3).

Mustikawati, T.A., Sunarti., Pangestuti, E. (2017). Analisis Pengembangan Sarana Prasarana Obyek Wisataalam Telaga Ngebel Dalam Meningkatkan Kesejahteraan Ekonomi Masyarakat. Jurnal Administrasi Bisnis, Vol.53(2).

Pajriah, S., (2018). Peran Sumber Daya Manusia Dalam Pengembangan Pariwisata Budaya di Kabupaten Ciamis. Jurnal Artefak: History And Education, 5(1)

Prafitri, G.R., \& Damayanti, M. (2016). Kapasitas Kelembagaan Dalam Pengembangan Desa Wisata (Studi Kasus: Desa Wisata Ketenger, Banyumas). Jurnal Pengembangan Kota 4(1).

Pramesti, A.D., \& Liana, Y. (2018). Potensi Daya Tarik Wisata Air Terjun Bur Bulet Sebagai Daya Tarik Wisata Alam Di Takengon Aceh Tengah. Jurnal Ilmu Administrasi Publik, 6(2)

Priyanto \& Safitri, D. (2016). Pengembangan Potensi Desa Wisata Berbasis Budayatinjauan Terhadap Desa Wisata Di Jawa Tengah. Jurnal Vokasi Indonesia 4(1). 
Pujaastawa, I.B.G. 2019. Antropologi Pariwisata. Denpasar: Pustaka Larasan.

Rusilowati, U. \& Atmaja, F.J. (2019). Analisis Strategi Pengembangan Pemasaran Produk Sangdo Agriculture. Jurnal Ilmiah Feasible:Bisnis, Kewirausahaan \& Koperasi,Vol. 1(1)

Setiawan, R.I. (2016). Pengembangan Sumber Daya Manusia di Bidang Pariwisata: Perspektif Potensi Wisata Daerah Berkembang. Jurnal Penelitian Manajemen Terapan, 1(1).

Suchaina. (2014). Pengaruh Kualitas Fasilitas Sarana Dan Prasarana Terhadap Peningkatan Jumlah Pengunjung Wisata Danau Ranu Grati. Jurnal Psikologi, 2(2).

Syahrul, A.R. (2015). Pengaruh Daya Tarik, Fasilitas dan Aksesibilitas Terhadap Keputusan Wisatawan Asing Berkunjung Kembali ke Aloita Resort Di Kab. Kep. Mentawai. Jurnal Pelangi Vol. 7(1).

Raharjana, D.T. (2012). Membangun Pariwisata Bersama Rakyat:Kajian Partisipasi Lokal Dalam Membangun Desa Wisata di Dieng Plateau. Jurnal Kawistra Vol. 2(3).

Triyono, J., Damiasih, Sudiro,S. (2018). Pengaruh Daya Tarik dan Promosi Wisata Terhadap Kepuasaan Pengunjung Kampoeng Wisata di Desa Melikan Kabupatean Klaten. Jurnal Kepariwisataan, 12 (1). 